\title{
A STUDY OF RENAL TUMOURS FOR A PERIOD OF 5 YEARS
}

\author{
Satyasri Karri ${ }^{1}$, B. V. S. Kartheek ${ }^{2}$
}

${ }^{1}$ Associate Professor, Department of Pathology, RIMS, Srikakulam, Andhra Pradesh, India.

${ }^{2}$ Assistant Professor, Department of Pathology, Andhra Medical College, Visakhapatnam, Andhra Pradesh, India.

\section{BACKGROUND}

ABSTRACT

Cancer of the kidney amounts to $2 \%$ of the total human cancer burden with approximately 1,90, 000 new cases diagnosed each year. They occur in all regions of the world with a higher incidence in developed countries. Etiological factors include environmental carcinogens (tobacco smoking) and life style factors, in particular obesity. Although renal tumours can be completely removed surgically, haematogenous metastases are frequent and may occur at an early stage of the disease. To understand the incidence of various renal tumours in relation to age, sex, location and frequency, a study was taken up for a period of 5 years. Histopathological study was carried out at Department of Pathology, Andhra Medical College, Visakhapatnam on the nephrectomy specimens received from King George Hospital.

\section{METHODS}

The present observational study is carried out in the department of pathology, Andhra Medical College. The material for the study included nephrectomy specimens received from surgical departments of King George Hospital. The relevant clinical history and data were taken in a prescribed proforma. The tissue blocks were prepared, stained with Haematoxylin and Eosin stains, and special stains like PAS, Van-Gieson and reticulin. IHC studies were done for relevant tumours. Our study included 55 nephrectomy specimens with tumours which were classified according to UICC/ TNM classification.

\section{RESULTS}

In the present study, the total number of nephrectomy specimens received were 90 . Out of these specimens, 55 were removed for tumours either benign or malignant and the remaining 35 showed non-neoplastic conditions like hydronephrosis, chronic pyelonephritis, tuberculosis pyelonephritis and calculi. The incidence of tumours is found to be high in males compared to females in both the age groups.

\section{CONCLUSIONS}

Among the adult renal tumours, RCC was the most common malignancy observed. Majority of the tumours occurred in the fifth and sixth decades. As there is a significant difference in the outcome for different histological subtypes of RCC, subtyping was done. Clear cell RCC was the most common type observed and the results correlated with literature.

HOW TO CITE THIS ARTICLE: Karri S, Kartheek BVS. A study of renal tumours for a period of 5 years. J. Evolution Med. Dent. Sci. 2019;8(20):1602-1607, DOI: 10.14260/jemds/2019/355

\section{BACKGROUND}

Renal tumours comprise a diverse spectrum of neoplastic lesions with patterns that are relatively distinct for children and adults. Cancer of the kidney amounts to $2 \%$ of the total human cancer burden with approximately 1, 90, 000 new cases diagnosed each year. ${ }^{1}$ They occur in all regions of world with a preference for developed countries. Etiological factors include environmental carcinogens (Tobacco smoking) and life style factors, in particular obesity.

The tumours of the kidney are a complex group, their histogenesis is controversial, their structure variable and in their behaviour are capricious. Various classifications have been proposed the earliest being that of Ewing (1940), Lucke \& Schlumberger (1957), Meredith (1957), Allen (1962) etc. A more complete understanding of the genes involved in the pathogenesis of these tumours has led to the formulation of new classifications.

'Financial or Other Competing Interest': None.

Submission 30-03-2019, Peer Review 05-05-2019,

Acceptance 11-05-2019, Published 20-05-2019.

Corresponding Author:

Dr. B. V.S. Kartheek,

10-9-1/2, Ramnagar,

Near GVMC, Visakhapatnam-530002,

Andhra Pradesh, India.

E-mail: kartheekbvs84@gmail.com

DOI: $10.14260 /$ jemds $/ 2019 / 355$
Conferences held in Heidelberg in October 1996 and in Rochester, Minnesota in March 1997, both with an international faculty, have led to the publications of consensus diagnostic categories. ${ }^{2}$

In most cases an accurate diagnosis can be reached using routine readily available histopathology techniques. In only a small proportion of complex cases is there a requirement for sophisticated molecular genetics in diagnosis.

In this context, to understand the incidence of various renal tumours in relation to age, sex, location and frequency, a study was taken up for a period of 5 years. Diagnostic histopathological study was carried out at the Upgraded department of Pathology, Andhra Medical College, Visakhapatnam on the nephrectomy specimens received from surgical departments of King George Hospital.

This study is undertaken to evaluate the complete spectrum of renal tumours with relation to age, sex, habits in a tertiary care hospital catering to the patients of north coastal Andhra Pradesh.

\section{Aims and Objectives}

1. To know the incidence of different types of renal tumours for a period of five years.

2. To undertake retrospective and prospective study of various renal tumours in relation to age, sex and side distribution.

3. To compare the results of the study with other studies. 


\begin{tabular}{|c|c|c|c|}
\hline Sl. No. & Nature of Tumour & Number of Cases & $\%$ \\
\hline I. & Non-neoplastic & 35 & 38.9 \\
\hline II. & $\begin{array}{l}\text { Neoplastic } \\
\text { (a) Benign }\end{array}$ & 2 & 2.2 \\
\hline & (b) Malignant & 53 & 58.9 \\
\hline & Total & 90 & 100 \\
\hline \multicolumn{4}{|c|}{ Table 1. Nature of The Tumour } \\
\hline
\end{tabular}

\begin{tabular}{|c|c|c|c|}
\hline Sl. No. & Tumour & No. of Cases & $\mathbf{\%}$ \\
\hline \multicolumn{4}{|c|}{ Benign } \\
\hline 1. & Multi cystic-nephroma & 1 & 1.8 \\
\hline 2. & Angio-myolipoma & 1 & 1.8 \\
\hline \multicolumn{3}{|c|}{ Malignant } \\
\hline 1. & Renal cell carcinoma & 30 & 54.5 \\
\hline 2. & Wilm's tumour & 18 & 32.9 \\
\hline 3. & Urothelial carcinoma & 2 & 3.6 \\
\hline 4. & Squamous cell carcinoma & 2 & 3.6 \\
\hline 5. & Mesoblastic nephroma & 1 & 1.8 \\
\hline \multicolumn{2}{|c|}{ Total } & $\mathbf{5 5}$ & $\mathbf{1 0 0}$ \\
\hline
\end{tabular}

Table 2. Relative Frequency of Different Tumours

\begin{tabular}{|c|c|c|c|c|c|}
\hline Sl. No. & Age in Years & Male & Female & Total & \% \\
\hline 1. & $0-10$ & 11 & 9 & 20 & 36.4 \\
\hline 2. & $11-20$ & - & 1 & 1 & 1.7 \\
\hline 3. & $21-30$ & - & 2 & 2 & 3.6 \\
\hline 4. & $31-40$ & 2 & 2 & 4 & 7.3 \\
\hline 5. & $41-50$ & 9 & - & 9 & 16.4 \\
\hline 6. & $51-60$ & 9 & 2 & 11 & 20.0 \\
\hline 7. & $61-70$ & 5 & 1 & 6 & 10.9 \\
\hline 8. & $71-80$ & 1 & 1 & 2 & 3.6 \\
\hline & Total & $\mathbf{3 7}$ & $\mathbf{1 8}$ & $\mathbf{5 5}$ & $\mathbf{1 0 0}$ \\
\hline
\end{tabular}

Table 3. Age \& Sex Incidence of Renal Tumours

\begin{tabular}{|c|c|c|c|}
\hline Sl. No. & Complaint & No. of Cases & $\%$ \\
\hline 1. & Lump abdomen & 25 & 45.5 \\
\hline 2. & Flank pain & 12 & 21.8 \\
\hline 3. & Hematuria & 9 & 16.4 \\
\hline 4. & Fever & 2 & 3.6 \\
\hline 5. & Weight Loss & 5 & 9.1 \\
\hline 6. & Anaemia & 1 & 1.8 \\
\hline 7. & $\begin{array}{c}\text { Intestinal } \\
\text { obstruction }\end{array}$ & 1 & 1.8 \\
\hline & Total & 55 & 100 \\
\hline \multicolumn{4}{|c|}{ Table 4. Clinical Features } \\
\hline
\end{tabular}

\begin{tabular}{|c|c|c|c|c|c|}
\hline Sl. No. & Age in Years & Male & Female & Total & \% \\
\hline 1. & $0-10$ & - & 1 & 1 & 3.3 \\
\hline 2. & $11-20$ & - & - & - & - \\
\hline 3. & $21-30$ & - & 1 & 1 & 3.3 \\
\hline 4. & $31-40$ & - & 2 & 2 & 6.6 \\
\hline 5. & $41-50$ & 8 & 1 & 9 & 30.0 \\
\hline 6. & $51-60$ & 9 & 1 & 10 & 33.3 \\
\hline 7. & $61-70$ & 5 & 1 & 6 & 20.0 \\
\hline 8. & $71-80$ & - & 1 & 1 & 3.3 \\
\hline \multicolumn{7}{|c|}{ Total } & $\mathbf{2 2}$ & $\mathbf{8}$ & $\mathbf{3 0}$ & $\mathbf{1 0 0}$ \\
\hline \multicolumn{6}{|c|}{ Table 5ge \& Sex Distribution of RCC } \\
\hline
\end{tabular}

\begin{tabular}{|c|c|c|c|}
\hline Sl. No. & Histology & No. of Cases & $\mathbf{\%}$ \\
\hline 1. & Clear cell RCC & 15 & 50 \\
\hline 2. & $\begin{array}{c}\text { Mixed clear \& granular cell } \\
\text { RCC }\end{array}$ & 9 & 30 \\
\hline 3. & Papillary RCC & 3 & 10 \\
\hline 4. & Chromophobe RCC & 1 & 3.3 \\
\hline
\end{tabular}

\begin{tabular}{|c|c|c|c|}
\hline 5. & Multi-cystic RCC & 1 & 3.3 \\
\hline 6. & Juvenile RCC & 1 & 3.3 \\
\hline & Total & 30 & 100 \\
\hline \multicolumn{4}{|c|}{ Table 6. Histological Sub-Types of RCC } \\
\hline
\end{tabular}

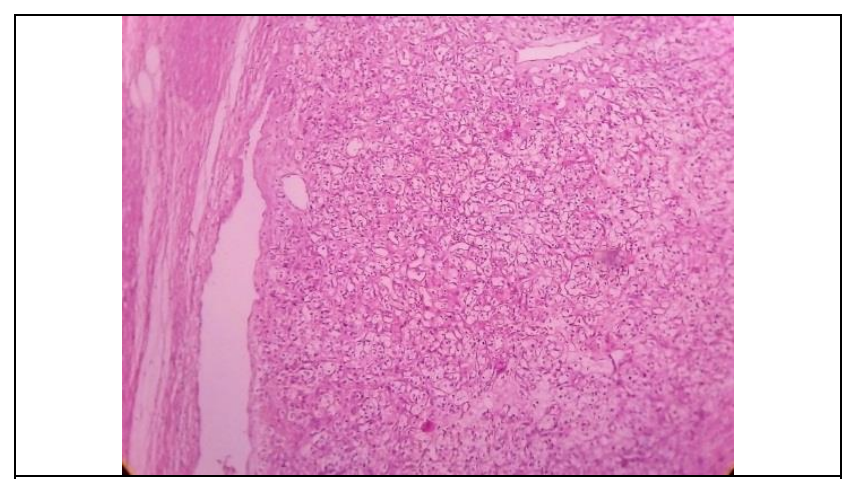

Figure 1. RCC-Clear Cell Type-Photomicrograph Showing Clear Cells Separated by Delicate Vasculature (H \& E, 100x)
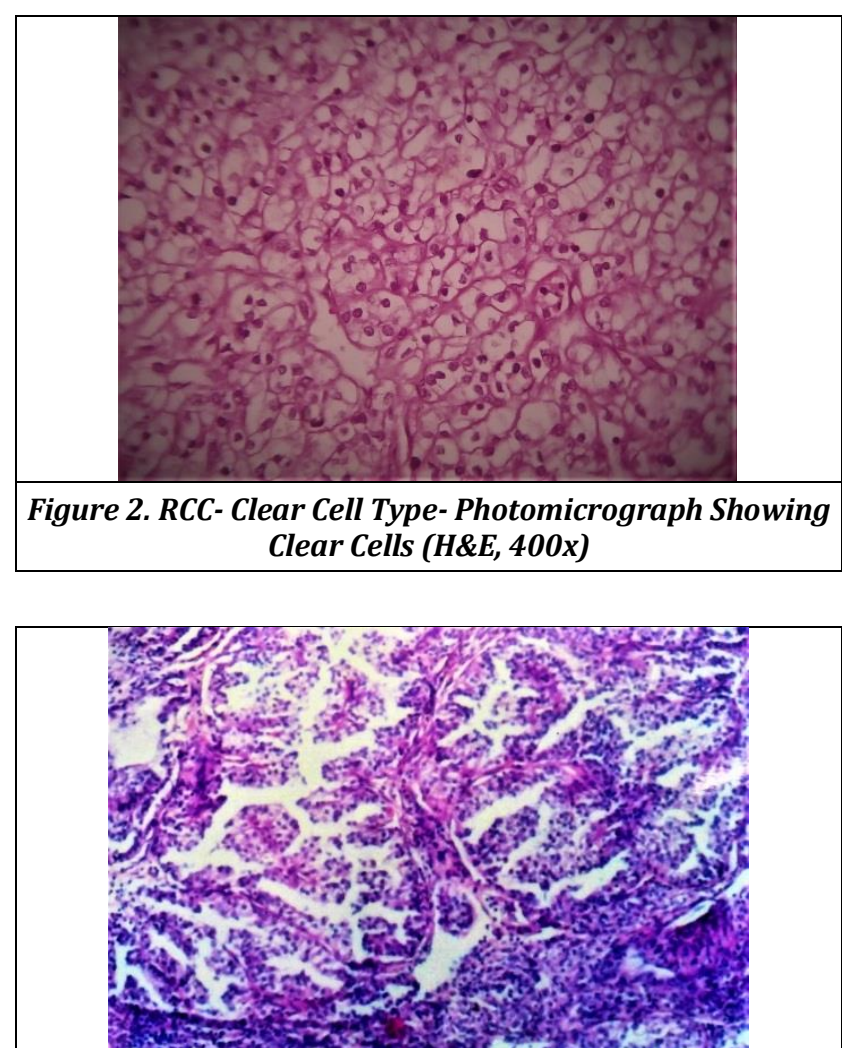

Figure 3. Papillary Renal Cell Carcinoma Subtype 1 (H\&E, 40X)

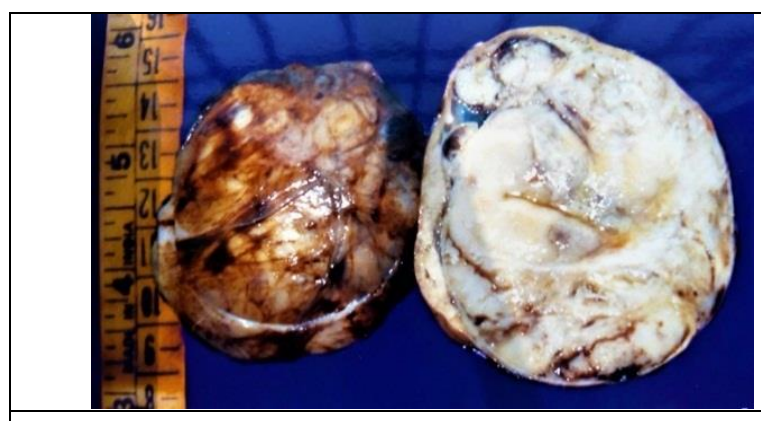

Figure 4. Gross Picture of Wilm's Tumour Showing Soft Brain like Appearance 


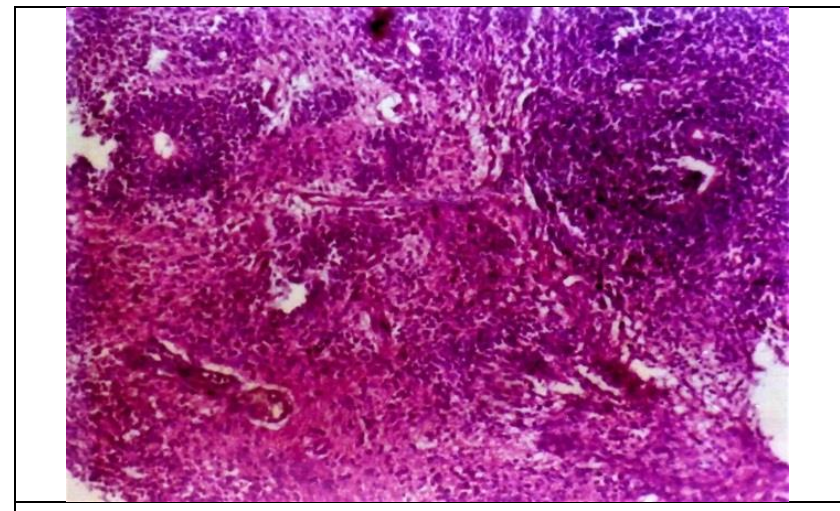

Figure 5. Wilm's Tumour Triphasic Histology. (H \& E, 40X)
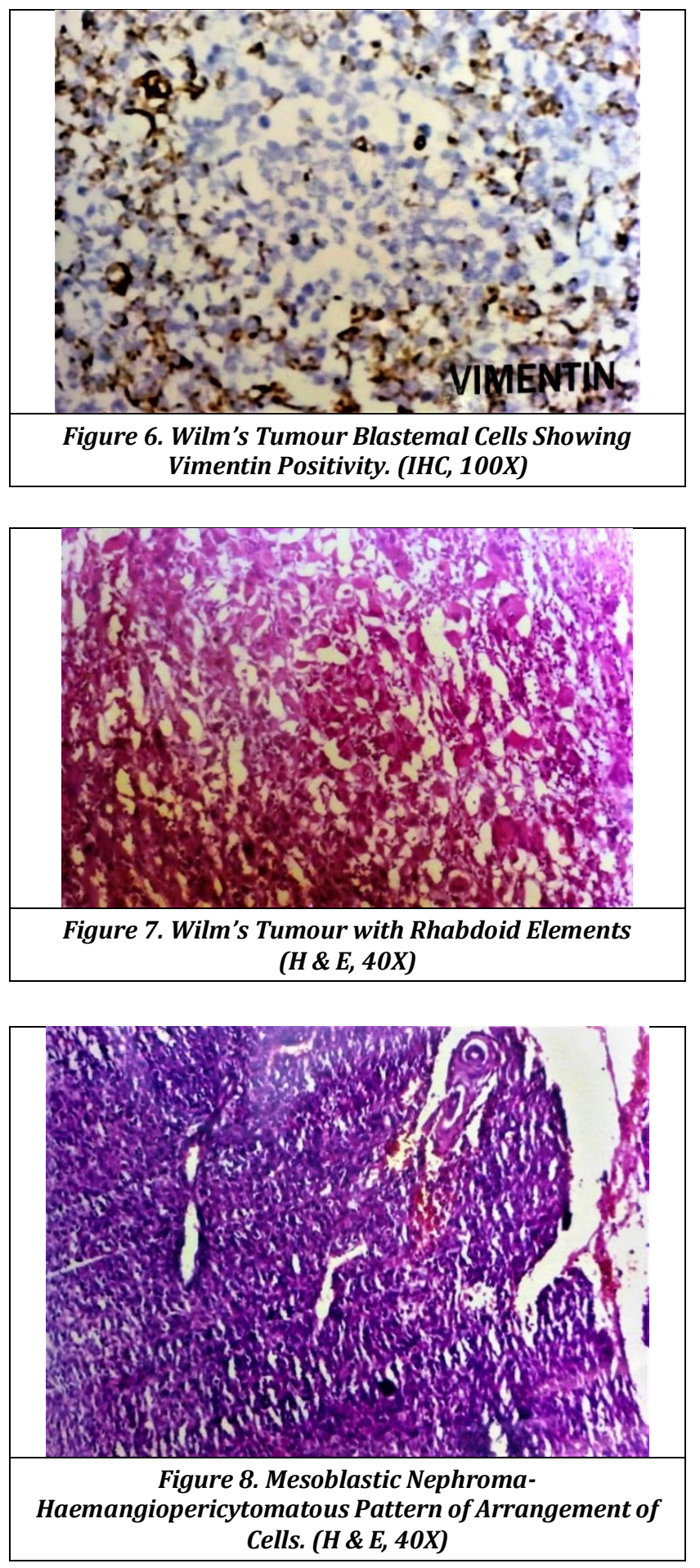

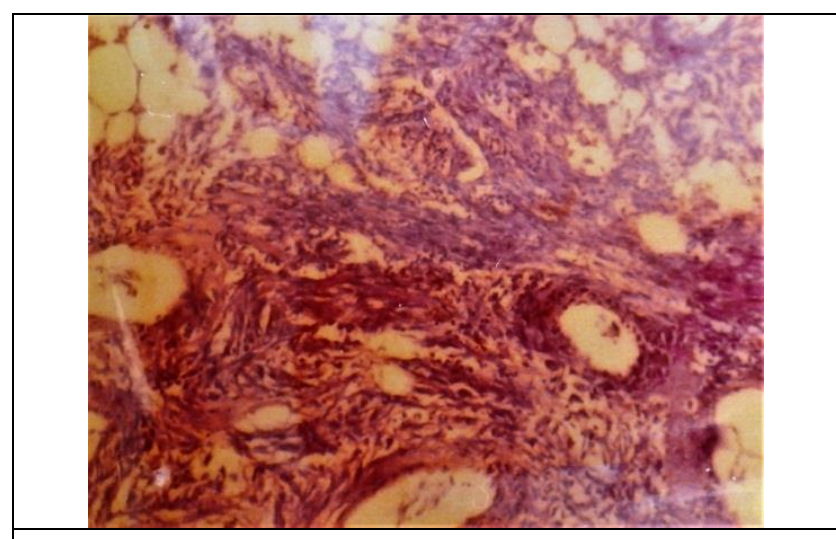

Figure 9. Angiomyolipoma- Tumour Composed of Adipose Tissue, Smooth Muscle \& Blood Vessels. (H \& E, 40X)

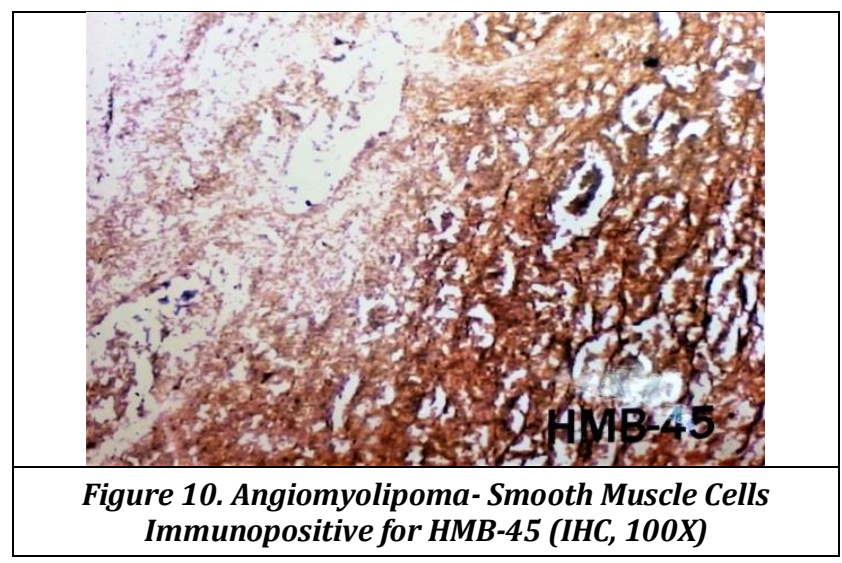

\section{METHODS}

Study Design

Observational study.

The present study is carried out in the department of pathology, Andhra Medical College. The material for the study included nephrectomy specimens received from surgical departments of King George Hospital. The relevant clinical history and data were taken in a prescribed proforma. The tissue blocks were prepared, stained with Haematoxylin and Eosin stains, and special stains like PAS, Van-Gieson and reticulin. IHC studies were done for relevant tumours. Our study included 55 nephrectomy specimens with tumours which were classified according to UICC/ TNM classification.

Sample size was taken based on the convenience of the study.

\section{Statistical Methods}

The statistical package for social science $\{$ SPSS $\}$ version 20 will be used for data analysis. Mean, median, and SD are used to describe quantitative data. Qualitative data are summarized using frequency and percentage.

\section{RESULTS}

Total nephrectomy specimens received were 90 . Out of these, 55 specimens were removed for tumours, either benign or malignant and the remaining 35 showed non-neoplastic conditions like hydronephrosis, chronic pyelonephritis, tuberculous pyelonephritis and calculi. (Table 1) Majority of the tumours in the present study were malignant and a total of 7 different types of tumours were observed. Most of the tumours were renal cell carcinomas followed by Wilms 
tumour. The patients are categorized into 8 age groups. The $\mathrm{M}$ : $\mathrm{F}$ ratio is 2.1:1. Renal tumours are common in the $1^{\text {st }}$ and $6^{\text {th }}$ decades of life and the incidence is found to be high in males compared to females. In majority of the patients, lump abdomen was the presenting complaint (45.5\%). $21.8 \%$ of cases. There was pain in either flanks. Hematuria is observed in $16.4 \%$ of cases. The most common malignant renal tumour was renal cell carcinoma (RCC) with a high incidence in $5^{\text {th }}$ and $6^{\text {th }}$ decades with a male preponderance of $2.8: 1$ ratio. Out of the 30 cases, multi-focality was observed in $13.3 \%$ of the cases and in the remaining $88.7 \%$ of cases the lesion was unifocal. No case of bilaterality was recorded.

\section{DISCUSSION}

Renal tumours are being increasingly detected nowadays with better imaging techniques and at an early stage due to regular health check-ups. They are mostly malignant tumours arising from the renal parenchyma. The new WHO classification and the American Joint Committee on Cancer (AJCC) staging system for renal tumour help in the prediction of tumour prognosis, therapeutic response, monitoring of recurrences and patient follow up.

Renal neoplasms have different distribution patterns in different age groups and in either sex. Malignant and benign renal tumours tend to have a contrasting sex distribution and age incidence.

\section{Relative Frequency of Different Tumours (Table 2)}

Out of the total of 55 tumours, majority were malignant (96.4\%) and only $3.6 \%$ were benign. The two benign tumours were angio-myolipoma and multi cystic-nephroma. Benign tumours are small and often multiple. They usually do not cause any symptoms and are an incidental finding during an ultrasound abdomen or in nephrectomy specimens removed for other causes or during autopsy.

Among malignant tumours, majority were renal cell carcinomas (54.5\%). Wilm's tumour is the second most common malignancy (32.9\%). Two cases each of urothelial carcinoma of the renal pelvis, squamous cell carcinoma and one case of mesoblastic nephroma were the other tumours recorded in the study. The study correlated with the study of Mahul B, Amin et al who recorded an incidence of $93 \%$ for malignant tumours in their study. ${ }^{3}$

\section{Age \& Sex Incidence of Renal Tumours (Table 3)}

Renal tumours are found to have a bimodal age distribution. They were found to be common in children less than 10 years $(36.4 \%)$ and in adults in the $5^{\text {th }}$ and $6^{\text {th }}$ decades $(36.4 \%)$. Wilm's tumour is the only renal tumour occurring in the $1^{\text {st }}$ decade whereas majority of the adult renal tumours in the $5^{\text {th }}$ and $6^{\text {th }}$ decades were malignant renal epithelial tumours. In the present study, benign and malignant tumours are found to be more common in males with a M:F ratio of 2.1:1. This male preponderance of renal tumours is well known.

\section{Renal Cell Carcinoma (RCC) (Figures 1 \& 2)}

Renal Cell Carcinoma accounts for approximately $2 \%$ of adult malignancies and $85-90 \%$ of neoplasms arising from the kidney. It is seen that $56.6 \%$ of all renal tumours that occurred during the period were renal cell carcinomas. Out of the 30 cases, 22 were male patients, 18 of whom were smokers. One female patient was a smoker and one patient were obese. Cigarette or chutta smoking is thus found to be associated with RCC in our study. Coughlin SS et al in their studies found smoking as the most important risk factor for RCC.

RCC usually presents with hematuria (59\%), flank pain (41\%) or abdominal mass (45\%). The combination of these three features is classically regarded as the diagnostic triad of RCC is seen only in $9 \%$ of the patients. ${ }^{4}$ In our study, 3 patients $(10 \%)$ presented with a classical triad. In 18 cases (60\%) the main symptom was hematuria, either alone or with lump abdomen. One case presented with intestinal obstruction and severe anaemia was the presenting symptom in a 75-year-old female. (Table 4)

In the study 30 cases of RCC were observed. Majority of the tumours occurred in the age groups 51-60 (33.3\%) and 41-50 (30\%).(Table 5) RCC is a tumour of adults with average age and diagnosis being 55- 60 years according to Motzer. ${ }^{5}$ In a study by Ying Cao et al from Department of Pathology and Urology, Chicago 112 tumours from a single institution were analysed. They found renal tumours to be common between ages of 50 and $70 .^{6}$ Results of several studies indicate that clear cell RCC is the most common tumour in the age groups 50-70.7 According to Jose. I. Diaz, Linda B Mora RCC is extremely rare in the first two decades of life. ${ }^{8}$ The youngest case in the present study was a 9-year-old female child and the oldest was a 75 years old lady. Tumours were more common in males than in females with a M: F ratio of 2.8:1. (Table 5)

In 50\% (15) of the cases most common clear cell patterns was observed. The cells are arranged in solid, alveolar and acinar patterns separated by stroma with a regular network of small thin walled blood vessels, a diagnostically helpful characteristic of this tumour. Tubular, papillary and cystic formations were also seen. A mild lymphocytic infiltrate was seen in some cases. The cells were large, round to polyhedral with clear cytoplasm and sharply outlined boundaries (Vegetable cells). In 9 cases (30\%), cells with eosinophilic granular cytoplasm were seen apart from clear cells. Out of these 9 cases, three had more than $50 \%$ granular cells.

The nuclei were round and centrally located with prominent eosinophilic nucleoli. Some of the tumours showed pink eosinophilic globules known as glassy hyaline globules (GHG). According to Hes $\mathrm{O}$, Michal $\mathrm{M}$ the presence of GHG in a renal tumour may be of aid for excluding a diagnosis of chromophobe RCC or oncocytoma. They observed GHG in 49 of 64 cases of granular cell and mixed cell/ granular cell RCC. ${ }^{9}$ No GHG were found in 22 cases of papillary RCC and 26 cases of renal oncocytoma. In our study also GHG were observed in mixed clear cell and granular cell tumours. (Table 6)

\section{Papillary Renal Cell Carcinoma (Figure 3)}

In our study, we observed 3 cases (10\%) of papillary RCC. The incidence quoted in the literature by Mydlo JH, Bard RH is approximately $10 \% .{ }^{10}$ All the three cases occurred in men of $5^{\text {th }}$ and $6^{\text {th }}$ decade. The histopathology of the showed cells arranged in papillary formations and tubules. The papillae were lined by small cells with scanty cytoplasm in two casessub type and in one case the tumour cells had eosinophilic cytoplasm and high nuclear-subtype 2 . The fibro-vascular core showed aggregates of foamy macrophages. The nuclear 
grade based on Fuhram system is grade I in two cases and grade III in one case.

\section{Chromophobe Renal Cell Carcinoma}

A single case of chromophobe RCC was observed in our study. The patient was a male aged 50 years. This tumour should be differentiated from the conventional and papillary RCC as according to Cheville JC, Loh'se CM etal there are significant differences in the outcome for the different histologic subtypes of RCC.11 Crotty JB, Farrow GM, et al observed a $100 \% 5$ years survival of patients with chromophobe RCC thus emphasizing the need for histological subtyping of RCC. 12

\section{Multilocular Cystic Renal Cell Carcinoma}

One case of multilocular cystic RCC was observed in our study. It has to be differentiated from conventional RCC with cystic degeneration. The diagnoses of clear cell RCC with cystic change was excluded in this case as there were no expansile nodules of malignant cells. The Mainz Classification of renal cell tumours states that the rare cystic multi -locular variant has very good prognosis and metastasis is rare. ${ }^{8}$ David. A. Brinker et al in their studies also noted patients with multi cystic RCC to have a better prognosis compared to other histologic sub-types. ${ }^{13}$

\section{Wilms' Tumour (Figures 4, 5, 6, 7 \& 8)}

Wilms' tumour was the second most common tumour observed in our study. All the 18 cases recorded were seen in children the youngest case was a 3 months old male child while the oldest case recorded was an eleven-year-old girl. In Hardwick Stowens series the maximum age of diagnosis was $<1$ year. Similar findings were note in our study. ${ }^{14}$

There was no sex predilection and except for 1 case which was bilateral, rest of the cases were unilateral with equal distribution in both kidneys. 10 cases occurred before the age of 3 years and in less than 5 years age group the number was $13(72.2 \%)$. In majority of cases the child was brought to the hospital on observing a mass in the abdomen. In 5 cases the main complaint was fever and in 2 cases there was history of loss of weight and appetite. U/S findings were available for most of the cases (83.3\%). Chevalier G, et al'“, Li-C-M, Guo, M etal stated that Wilms' tumour is a prototypical example of a neoplastic process that faithfully recapitulates embryo genesis at the morphologic and molecular levels.15,16 According to Crist WM, Kunle et al \& Kissane JM, Dehner LP, Webber BL et al, $50 \%$ of Wilm's tumour occur in children before the age of 3 years. ${ }^{17,18}$ Our results are correlating with them.

According to Vujamic GN, Kelsey A, a pre-chemotherapy biopsy helps to know the exact histopathological picture. ${ }^{19}$ The classic triphasic histology consisting of blastemal, epithelial and mesenchymal component were observed in $61.1 \%$ of cases. In $27.8 \%$ there was a biphasic pattern. Out of which blastemal component was dominating in $16.7 \%$ and epithelial elements were dominant in $11.1 \%$ of cases. 1 case of Wilms' with teratoid features and one case with rhabdoid elements were observed in the study. Two cases received chemotherapy prior to nephrectomy. Their histopathology showed minimal blastemal elements and extensive areas of necrosis, cystic change and few papillary formations Wilms' tumour with predominant blastemal component must be differentiated from other small round cell tumours. A careful search usually reveals an epithelial component. immunohistochemistry is helpful in difficult cases-Vimentin positive.

When grading was based on the features of anaplasia, $83.3 \%$ showed a favourable histology, whereas in $16.7 \%$ the histology was unfavourable. The latter are expected to give a poor response to chemotherapy. A thorough sampling is necessary to evaluate this feature according to Zuppan CW. ${ }^{20}$ In the study all the cases with unfavourable histology were seen in children $>5$ Years of age. This probably explains the poor prognosis seen in this age group compared to the $<5$ years age.

\section{Mesoblastic Nephroma (Figures 8)}

In our study a case of mesoblastic nephroma was observed in a six months male child. Howeii CG, et al, based on a study on 51 patients with mesoblastic nephroma states that a large majority are cured following nephrectomy. Hence the histopathology distinction is important as clinically and radiographically they are diagnosed as Wilms' tumour. ${ }^{21}$

\section{Multi-Cystic Nephroma}

A single case of multicystic nephroma was observed in our study. The patient was a 7 years old male child who presented with abdominal lump and retention of urine. Joshi and Beckwith suggested more definite criteria consisting of:-

1. The lesion is composed of only cysts and septae.

2. It is discrete well-demarcated mass from adjacent renal parenchyma.

3. Septae are the only solid part of the tumour.

4. Cysts are lined by flattened, cuboidal or hob-nail epithelium.

5. Septa are composed of fibrous tissue in which well differentiated tubules may be present. ${ }^{22}$

In our case most of the above criteria were met with confirming the diagnosis.

\section{Angiomyolipoma (Figures 9 \&10)}

A case of renal angiomyolipoma was observed in our study. It was from a 40 years old male who had an injury to spleen in a road accident. The tumour was an incidental finding. HMB-45 was positive in Smooth muscle cells. Many morphological variants of angio-myolipoma are recorded in relation to relative proportions of various components. According to Oesterling J. E., Fishmen E, they are benign, and excision is usually curative. ${ }^{23}$

\section{Tumours of Renal Pelvis Urothelial Carcinoma}

In our study 2 cases of urothelial carcinoma of renal pelvis were observed. The 2 patients were a male and a female in the fifth and seventh decade respectively. Gross: Both the tumours were located in the renal pelvis. They were solid. Gray-white with pushing borders compressing the adjacent renal parenchyma. Guinan. $\mathrm{P}$, et al, recorded $7 \%$ incidence of urothelial cancers among adult malignancies. ${ }^{24}$

The microscopic appearance of these tumours is identical to their homologs in the urinary bladder. The majority, according to literature are grade II or grade III. In our study the two cases were of grade II. 


\section{Squamous Cell Carcinoma}

In our study 2 cases of primary squamous cell carcinoma of the renal pelvis were observed. One of the tumours was associated with a calculus and the other tumour showed chronic pyelonephritis changes. One tumour occurred in a male aged 35 years and the second case was a 29 years female with chronic symptoms of pyelonephritis. Nativ 0 Reiman H. M. et al in their studies found squamous cell carcinoma of renal pelvis associated with renal calculi and chronic pyelonephritis. ${ }^{25}$ These tumours need to be differentiated from the routine tumours as according to Strobel SL et al, these tumours have a poor prognosis. ${ }^{26}$

\section{CONCLUSIONS}

Among the adult renal tumours, RCC was the most common malignancy observed. Majority of the tumours occurred in the fifth and sixth decades. As there is a significant difference in the outcome for different histological subtypes of RCC, subtyping was done. Clear cell RCC was the most common type observed and the results correlated with literature.

\section{REFERENCES}

[1] Eble JN, Sauter G, Epstein JI, et al, eds. Pathology and genetics of tumours of the urinary system and male genital organs. Lyon, France: IARC Press 2004.

[2] Kovacs G, Akhtar M, Beckwith BJ, et al. The Heidelberg classification of renal cell tumours. J Pathol 1997;183(2):131-3.

[3] Amin MB, Amin MB, Tamboli P, et al. Prognostic impact of histologic subtyping of adult renal epithelial neoplasms: an experience of 405 cases. Am J Surg Pathol 2002;26(3):281-91.

[4] Coughlin SS et al. Multiple risk factors intervention trail research group. Cancer 1997;79:2171-77.

[5] Skinner DG, Colvin RB, Vermillion CD, et al. Diagnosis and management of renal cell carcinoma. A clinical and pathologic study of 309 cases. Cancer 1971;28(5):1165-77.

[6] Motzer RJ, Bander NH, Nanus DM. Renal cell carcinoma. N Engl J Med 1996;335(12):865-75.

[7] Cao Y, Paner GP, Perry KT, et al. Renal neoplasms in younger adults: analysis of 112 tumours from a single institution according to the new 2004 World Health Organization classification and 2002 American Joint Committee on Cancer Staging System. Arch Path Lab Med 2005;129(4):487-91.

[8] Alpers CE. The kidney. In: Kumar V, Abbas AK, Fausto $\mathrm{N}$, et al, eds. Robbins and Cotran pathologic basis of disease. $8^{\text {th }}$ edn. Philadelphia: WB Saunders 2010:90570.

[9] Diaz JI, Mora LB, Hakam A. The Mainz classification of renal cell tumours. Cancer Control 1999;6(6):571-9.

[10] Hes O, Michal M, Sclu M, et al. GHG in granular cell carcinoma, chromophobe cell carcinoma, oncocytoma of the kidney. Ann Diagn Pathol 1998;2(1):12-8.
[11] Mydlo JH, Bard RH. Analysis of papillary renal adenocarcinoma. Urology 1987;30(6):529-34.

[12] Cheville JC, Lohse CM, Zincke H, et al. Comparison of outcome \& prognostic features among histologic subtypes of renal cell carcinoma. Am J Surg Pathol 2003;27(5):612-24.

[13] Crotty TB. Farrow GM, Lieber MM. Chromophobe cell renal carcinoma: clinicopathological features of 50 cases. J Urol 1995;154(3):964-7.

[14] Brinker DA, Amin MB, de Peralta-Venturina M, et al. Extensively necrotic cystic renal cell carcinoma: a clinicopathologic study with comparison to other cystic and necrotic renal cancers. Am J Surg Pathol 2000;24(7):988-95.

[15] Hardwick DF, Stowens D. Wilms tumour. J Urol 1961;85:903-10.

[16] Chevalier G, Yeger $H$, Martinerie C, et al. novH: differential expression in developing kidney and Wilm's tumours. Am J Pathol 1998;152(6):1563-75.

[17] Li CM, Guo M, Borczuk A, et al. Gene expression in Wilms' tumour mimics the earliest committed stage in the metanephric mesenchymal-epithelial transition. Am J Pathol 2002;160(6):2181-90.

[18] Crist WM, Kun LE. Common solid tumours of childhood. N Eng J Med 1991;324(7):461-71.

[19] Kissane JM, Dehner LP. Renal tumours \& tumour like lesions in paediatric patients. Paediatr Nephrol 1992;6(4):365-82.

[20] Vujanić GM, Harms D, Sandstedt B, et al. New definitions of focal and diffuse anaplasia in Wilms tumour: the International Society of Paediatric Oncology (SIOP) experience. Med Pediatr Oncol 199;32(5):317-23.

[21] Zuppan CW. Handling and evaulation of pediatric renal tumours. Am J Clin Pathol 1998;109(4 Suppl 1):S31-7.

[22] Howell CG, Othersen HB, Kiviat NE, et al. Therapy and outcome in 51 children with mesoblastic nephroma: a report of the National Wilms' tumour study. J Pediatr Surg 1982;17(6):826-31.

[23] Joshi VV, Beckwith JB. Multilocular cyst of the kidney (cystic nephroma) and cystic, partially differentiated nephroblastoma. Terminology and criteria for diagnosis. Cancer 1989;64(2):466-79.

[24] Oesterling JE, Fishman EK, Goldman SM, et al. The management of renal angiomyolipoma. J Urol 1986;135(6):1121-4.

[25] Guinan P, Vogelzang NJ, Randazzo R, et al. Renal pelvic cancer. A review of 611 patients treated in Illinois 1975-1985. Urology 1992;40(5):393-9.

[26] Nativ O, Reiman WM, Lieber MM, et al. Treatment of primary squamous cell carcinoma of the upper urinary tract. Cancer 1991;68(12):2575-8.

[27] Strobel SL, Jasper WS, Sharma HM, et al. Primary carcinoma of the renal pelvis \& ureter. Evaluation of clinical and pathological features. Arch Pathol lab Med 1984;108(9):697-700. 